UDC 331.522.4:338.436(477)

http://doi.org/10.21272/mmi.2019.2-07

JEL Classification: I22, 031, R23

Mykola Butko,

D.Sc., Professor, Chernihiv National University of Technology, Ukraine

Olha Popelo,

Ph.D., Associate Professor, Chernihiv National University of Technology, Ukraine

Igor Pishenin,

D.Sc., Professor, Kyiv Institute of Business and Technologies, Ukraine

\title{
INNOVATIONS IN HUMAN RESOURCES MANAGEMENT IN EUROINTEGRATION CONDITIONS: CASE FOR UKRAINIAN AGRO-INDUSTRIAL COMPLEX
}

\begin{abstract}
The growth rate of the agroindustry complex development and the effect of destabilizing factors on the business sectors lead to limitation of Ukrainian agrarian sector sustainable development. In the ongoing economic transformational conditions, the implementing of the innovations in human resources management is an important component of the company's system. The paper deals with analysing of the instruments to determine the economic efficiency of the labour potential at agribusiness companies and proposing the innovative model for the formation, development, and reproduction of labour potential. The authors developed the convergence indexes for estimating the labour protentional. In the paper, the grouping and ranking of the Ukrainian regions according to the convergence factor was conducted. The concept of integrated management of labour potential in the conditions of agro-industrial innovative development was developed. In the framework to increase the efficiency of labour protentional the authors allocated and emphasized the importance of the following components: production, finance, marketing, and transactions. In this case, the convergence factor based on the aggregate values of financial, production, marketing, and transaction efficiency. In the conditions of strengthening of European integration processes, the social vector of strategic development of the country requires the development and introduction of new management methods in all spheres of economic activity in order to increase their competitiveness. The implementation of the innovative model of the state's economic development requires significant modernization transformations. The Ukrainian agro-industrial complex is a key budget-forming element of the national economy. The proposed methodology will further improve the methods for assessing the effectiveness of labour potential management, as well as increase the readiness of employees to perceive innovations.
\end{abstract}

Keywords: potential, labour market, agro-industrial complex, management system, convergence, innovation.

Introduction. The bullet point among the company's strategic resources is effective human recourses management which should focus on developing the labour potential. Noted, that traditional methods to estimate the effectiveness of labour potential are not considering the exogenous and endogenous factors. In this case, it is necessary to develop and implement new approaches to estimate the labour's potential considering the qualitative and quantitative characteristics. However, the factors of complex economic relations have a significant impact on the vector relations of labour potential using. This is especially tangible in the scorecard of agricultural companies' activity during the last five years. In the context of the crisis economic tendencies, the analytical instruments to estimate the economic efficiency from the labour potential using at the companies should be conducted considering the comprehensive evaluation of financial marketing, production and transaction costs, which substantially effect on the results of the companies' economic activity. The indicative component of these factors considering the aggregated and integrated level of economic stability of agribusiness companies.

Literature Review. Traditionally, the economic approach to estimate the efficiency of companies' development is based on financial indicators. The reason for such positioning is the fact that financial flows act as the baseline indicator of economic development, but the performance rate does not always correspond to the real situation.

Cite as: Butko, M., Popelo, O., \& Pishenin, I. (2019). Innovations in Human Resources Management in Eurointegration Conditions: Case for Ukrainian Agro-Industrial Complex. Marketing and Management of Innovations, 2, 74-82. http://doi.org/10.21272/mmi.2019.2-07 
The powerful scientific background has been developed in that area. Thus, Mariana Viollaz in the paper (Viollaz, 2018) analyses how the labour market and labour market institutions reacted during recent crises. In early 1990s Estonia introduced a set of rather unique policy options like currency board as a ground for monetary policy, low taxes, open foreign trade policy, low public sector debts, annually balanced state budget etc. These measures caused very limited options to implement both monetary and fiscal policy. The macroeconomic adjustment will take place in such a situation through the labour market. In the case of Estonia, a very high labour market flexibility played a crucial role in the recent economic recession. The measures taken included a reduction of nominal wages, working hours and redundancies among employees. This indicates that the traditional institutional factors that protect workers and also could decrease the flexibility of the labour market, such as labour market regulation, social protection and union activities, are not very well developed in Estonia and do not have a significant effect on the outcomes of the labour market (Viollaz, 2018).

Javier Cano-Urbina empirically examines the relationship between the self-identity as Indigenous and earnings inequality in the Mexican labour market. Using Mexican Census data and a large set of wage covariates reveals the existence of an earnings penalty for self-identification as Indigenous (Javier et al., 2016). Marco Caliendo shows the German labour market after the Great Recession: successful reforms and future challenges (Caliendo et al., 2012). Jo Ritzen and Klaus F Zimmermann sketch a visionary strategy for Europe in which full employment is quickly regained by 2020, income inequality is reduced and the economies are more sustainable. We call this scenario "vibrant". It is contrasted with what would happen if present policies continue within the European Union (EU) and its member states. In the vibrant scenario, full employment is regained through more policy attention toward innovation and its underlying research and development (R\&D), accompanied by the doctoral student more labour mobility within and between EU countries, in combination with a selective immigration policy based on labour market shortages. The road to full employment is embedded in a landscape with less income inequality and more «greening» of EU member states' economies. We translate the vibrant scenario into policy proposals distinguishing between the role of the EU and that of the member states (Ritzen et al., 2014). Jozef Konings and Luca Marcolin analyses do wages reflect labour productivity? The authors point out that classic economic theory applied to the labour market assumes that markets are perfectly informed and able to allocate workers in open vacancies. These workers are paid a salary equal to their marginal product of labour since labour supply and demand are both satisfied. In the real world, however, this condition might not hold: many market frictions exist which are triggered by imperfect information and institutional factors such as employment protection, unemployment benefits, collective bargaining, minimum wages and taxation (Konings et al., 2014). Ronald Bachmann, Peggy Bechara, Anica Kramer and Sylvi Rzepka perform a micro-data based analysis of the labour market transitions in a large number of European countries and investigate how these transitions have been affected by the recent financial and economic crisis during its early phase (2008-2010). For this time period, the exogenous shock exerted by the economic and financial crisis can be assumed to be relatively similar across countries. After 2011, by contrast, the economic development was much more divergent across Europe, making it much more difficult to conceptually isolate differences in shocks from differences in labour market reactions (Bachmann et al., 2015). The aforementioned and other leading scientists have made a significant contribution to the study of diverse labour market issues; however, the issue of assessing the effectiveness of labour potential is at the stage of study and needs further study and analysis. The problem of complex estimation of productivity of labour potential of agribusiness companies is thoroughly studied in the last period. Different aspects of this problem remain, which significantly actualizes additional scientific searches. The main problem of the assessed-analytical processes is the objective consideration of all defining factors that directly or indirectly affect the researcher category. Forming a model of complex evaluation of economic efficiency of evaluation of 
employment potential and simulation of relevant forecasts for the perspective, using the information base remains the actual tasks of economic science.

The main purpose of the paper is to study at the practically analytical level of application of complex valuation instruments of the economic efficiency of the labour potential using at the agribusiness companies and model development and reproduction of labour potential.

Methodology and research methods. The economic development of agribusiness companies is a dynamic category and is determined by the snowballing changes among the different indicators, so the results of analytical indicators and calculations affecting sustainable economic development showed the main trends of change different coefficients within the specific group of indicators. Methodological bases of efficiency evaluation of labour potential using are formed from the general scientific methods (system analysis, complex approach, program-target planning); analytical and prognostic methods (linear programming, probability theory, network planning, economic and statistical methods, economic expertise, financial audit); methodical methods used in other fields of science-sociology, economics, informatics, psychology (Melnyk, 2017a). The findings showed that the process to estimate the economic efficiency of the labour potential is a complex issue which provoke the considering of different factors with different influence on the investigated economic category (Melnyk, 2017b). Besides, the integral index of convergence coefficient contains from the indicator of the economic efficiency of agribusiness companies, which directly influence and determine the qualitative characteristic of it. This coefficient reveals the generalized information on the level of labour potential, qualitative and quantitative evaluation of its development, in case of the defining components of effective functioning of modern agribusiness companies.

The main indicator of the company sustainable development is the indicators which described the financial results: increase of profit, decrease of cost, a decrease of internal yield rate, a decrease of the payback period of investment and decrease of financing level from other sources. In the paper the agro holding companies were selected for the period 2010-2017. Noted, that all analysed companies had the stable development and increased the sales volume. The calculation of complex indicators of company development was carried out in different directions and therefore used different approaches to their processing. In terms of a particular company, it is most expedient to use the method of calculation, which has a thoroughly logical explanation, based on the specificity of agro-industrial industry and peculiarities of activity of the concrete company. Positive dynamics of some coefficients of economic activity and financial independence testify to the high level of effective management of the company, on making effective management decisions and about possibilities of development of the company in long term. But the financial results do not fully consider the participation of labour potential as an economic category, therefore it is necessary to consider the indicators of productive results of labour potential: mastering innovative technologies, long-time production process, participation in new projects, level of tasks fulfilment, level of performing discipline. These indicators characterize the implementation of innovative technologies, performing discipline of specialists, appropriate professional abilities.

Research of the process of economic development of agribusiness companies allows asserting that this control system is a part of the complex economic indicators, which are considered by the company in the process of its activity lack of evaluation of marketing results restricts the content of the general evaluation of the management system as a process. The estimation of marketing results includes the following components: expansion of commodity markets, investment attractiveness of the company, increase of demand for products of a particular company, the realization of the system of changes in production technologies and competitive advantages of the company. However, the lack of effective evaluation causes certain management problems as a process.

The finding of analysing of on issues of labour potential efficiency it is outlined only general recommendations on the estimation of the necessity of such constituents, but not presented quantitative indicators to their value by traditional methods (Buriennikova et al., 2017). A detailed analysis of the 
paper showed the necessity of multifactorial estimation on economic, production, social component in conditions of incomplete certainty regarding the vector of their influence. The complex estimation of the labour potential among agribusiness companies is analytical and prognostically. For evaluation of structural and dynamic shifts and development of forecasting options of individual components of the labour potential, the estimation of both retrospectives and modern state of objects, on the basis of which the possible tendencies and variants are projected, are used. Development of labour potential and future status on a perspective with a certain lag (short-, medium and long-term). The methods of extrapolation are the most widespread and the most effective methods of forecasting. In general, extrapolating to the future revealed tendencies of development of the research object, which are reflected in the form of a dynamic series of indicators, which characterize it. These methods are based on the assumption that the change of factors that have an impact on the development of the research object will not be significant, and the revealed tendencies of its development are preserved further. This approach to forecasting is called «genetic» and provides for use of econometric models. As the most important factor determining the development of labour potential, the model should enter a time factor-trend. In this case, the procedure of extrapolating the revealed trends involves the choice of trending models of forecasting in the form of graphics, which most accurately describes a number of empirical data. In case the development of labour potential indirectly by market conditions of the most common forecasting models can have the following interpretations:

1. Linear $Y=a_{0}+a_{1} \times t-$ demand for labour potential is mainly satisfactory and grows evenly. In perspective, with sufficient and timely improvement of the system, the tendency to increase.

2. Logarithmic $Y=a_{0}+a_{1} \times \log t-$ demand for labour reserve is satisfied and gradually grows, but the rate of growth of labour potential is decreasing. In the future, the market will be full of saturation, the level of provision of needs in the labour resource will be closer to the rational standard, although the growth rate of demand is gradually decreasing.

3. Hyperbolic $Y=a_{0}+a_{1} / t$ - demand for labour potential is mainly satisfied, but it is a stable reduction. In the future, this service can be pushed out of the market or will be observed to reduce the range of users of this service.

4. Parabolic $Y=a_{0}+a_{1}^{t}-$ demand for labour potential of the agro industry is not satisfied and increases the constant pace. In the future, the market saturation will be quite slow, and the growth of demand for labour potential will remain rather high.

5. The second order parabola $Y=a_{0}+a_{1} \times t+a_{2} \times t^{2}-$ demand for labour potential is not satisfied and increases at a considerable pace.

However, not always informed about the previous stage of labour potential development is complete, reliable and exhaustive. Under such conditions (at the insufficient volume of retrospective information) the use of analytical (target or normative) modelling is possible. This method allows the analysis of external and internal communications of the research object to assess its future state, to reproduce alternative variants of its development. The use of this method should begin to determine the most probable purposes of development as it can be: increase of agricultural production volumes; product range expansion. On the basis of certain objectives, the feedback with the measures necessary for their achievement is established. Thus, perspective directions of labour potential development among agribusiness companies were formed. A separate problem is a phase of labour potential evaluation as an integral comparative assessment of the level of labour potential using and effectiveness of personnel reserve activities, which could be recommended for separate regions.

According to the proposed approach, it is necessary considering the influence of exogenous and endogenous factors on the development of labour potential, which is a prerequisite of scientific and technological progress and is based on the consideration of objective and subjective components. Consumption, reproduction in the process of functioning of the transport infrastructure is a material basis of labour potential. Subjective factors form a platform for the creation of general economic and social factors of rational use of labour potential. Organizational and management component includes 
M. Butko, O. Popelo, I. Pishenin. Innovations in Human Resources Management in Eurointegration Conditions: Case for Ukrainian Agro-Industrial Complex

management structure and appropriate methods of the labour potential management. The authors developed the coefficient of convergence to estimate the labour potential which reveals the generalized information about the level of labour potential using, qualitative and quantitative evaluation of its state, development and reproduction, in case of defining components of effective functioning of modern agribusiness companies. The authors emphasized the significance of production, finance, marketing and transactions. One of the approaches of a more thorough study concerning the development of the methodology for calculating the integral indicator of labour potential-convergence coefficient (1) is the use of generalized values of financial, production, marketing and transaction efficiency.

The value of the convergence coefficient is determined on a scale that varies from zero (the worst value) to $100 \%$ (best value).

$$
K=1-\sum_{p=1}^{N} V_{p} \times \frac{\left|Y_{p}^{n}-Y_{p}^{f}\right|}{Y_{p}^{n}} \times 100
$$

where $\mathrm{k}$ is the coefficient of convergence - the integral indicator of the level of technological (social, economic) efficiency of the use of labour potential; $\Sigma V p=1$; $V p$ - «weight» indicators; $Y_{p}^{n}$ - normative (standard) state of process on the «P» indicator; $Y_{p}^{f}$ - the actual state of the process by the «P» indicator; $\left|Y_{p}^{n}-Y_{p}^{f}\right|-$ deviation of the actual state from the normative provided that exceeding the actual state of the regulatory environment is not considering, the difference is equal to zero to prevent the compensation of labour potential deficit by a parameter of excessive exceeding by second.

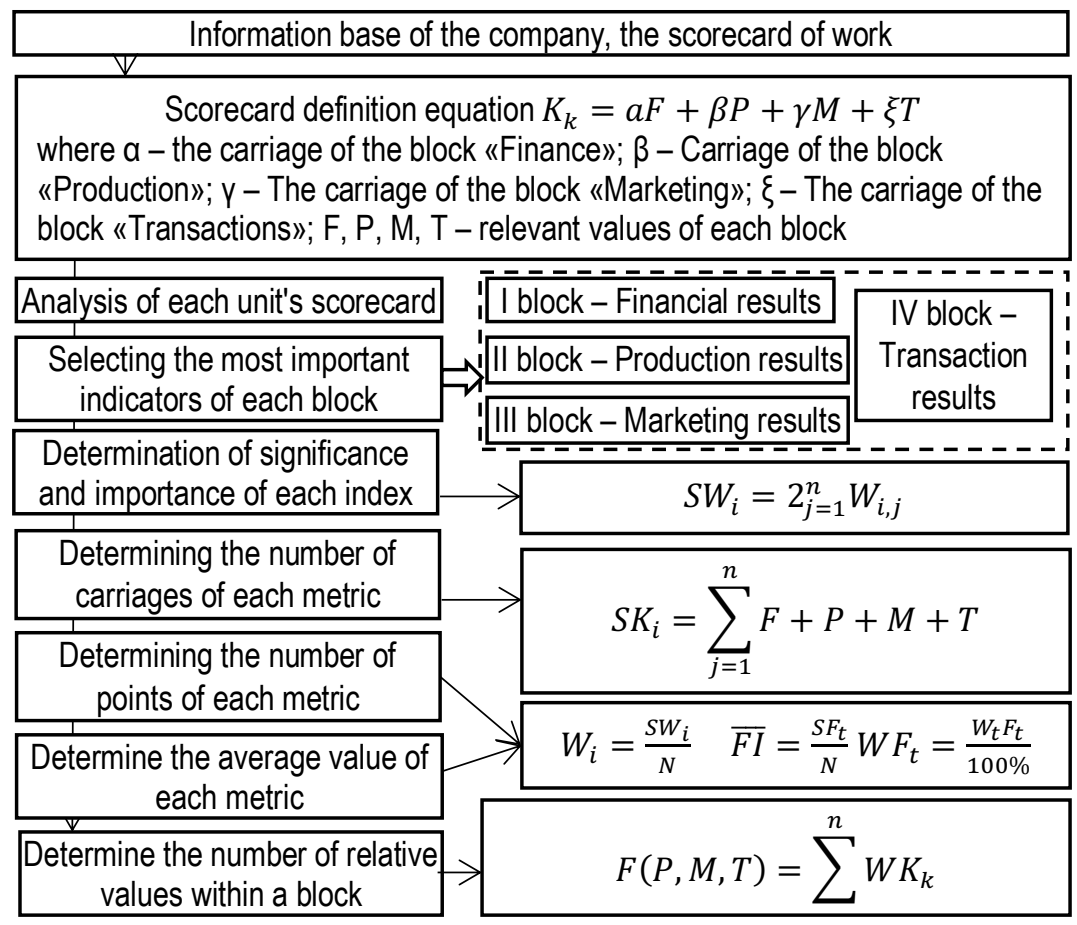

Figure 1. Method of determination of the convergence coefficient Sources: developed by the authors. 
M. Butko, O. Popelo, I. Pishenin. Innovations in Human Resources Management in Eurointegration Conditions: Case for Ukrainian Agro-Industrial Complex

Results. On the basis of the proposed method, the authors have calculated the convergence coefficient (CC) for Ukrainian regions. As a result of the calculation, four groups of regions were allocated: high-CC regions, regions with the $C C$ value above average, regions with average and low values of CC (Fig. 2).

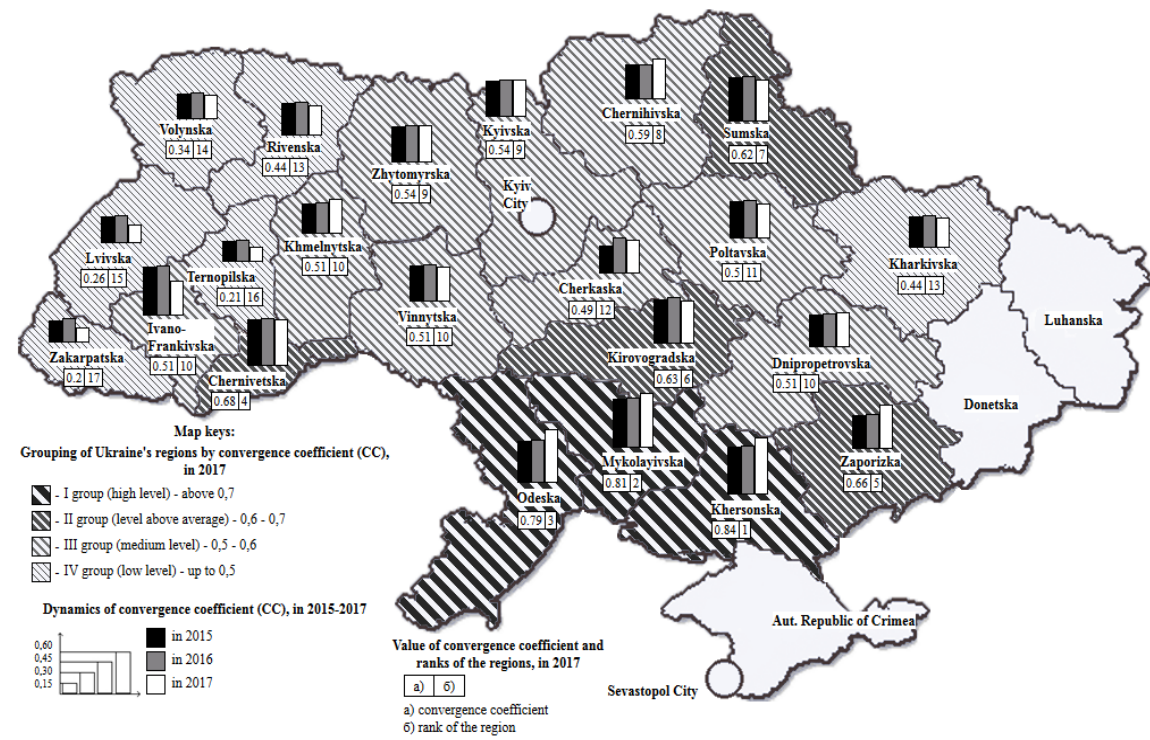

Figure 2. Grouping of Ukraine's regions by convergence coefficient

Sources: developed by the authors.

The first group of regions (with the values of convergence coefficient above 0.7) hit Mykolayiv, Odesa and Kherson regions; the second group (with the values of convergence coefficient within the 0.6-0.7) was attributed to Zaporizhzhya, Kirovohrad and Sumy regions; the third group (with the values of convergence coefficient within 0.5-0.6) included Vinnytsia, Dnipropetrovsk, Zhytomyr, IvanoFrankivsk, Kyiv, Poltava, Khmelnytsky and Chernihiv regions; the fourth group (with the values of convergence coefficient below 0.5) were the Volyn, Zakarpattia, L'viv, Rivne and Ternopil regions.

Modernization processes in the Ukrainian agro-industrial complex objectively requires the largescale transformations with purpose to develop and reproduce the labour potential for the agrarian companies. The practice of farming in agro shows that existing mechanisms of labour management at the basic level could not overcome such negative development trends, as a structural skewed toward the use of low-skill workers with low level.

The effectiveness of their use in the exploitation of the main means of production, absence of innovative technologies of training of specialists and deterioration of retraining of specialists from the number of rural residents. In Fig. 3 the authors proposed the concept of integrated management of labour potential in the conditions of innovative development of the agro-industrial complex. 
M. Butko, O. Popelo, I. Pishenin. Innovations in Human Resources Management in Eurointegration Conditions: Case for Ukrainian Agro-Industrial Complex

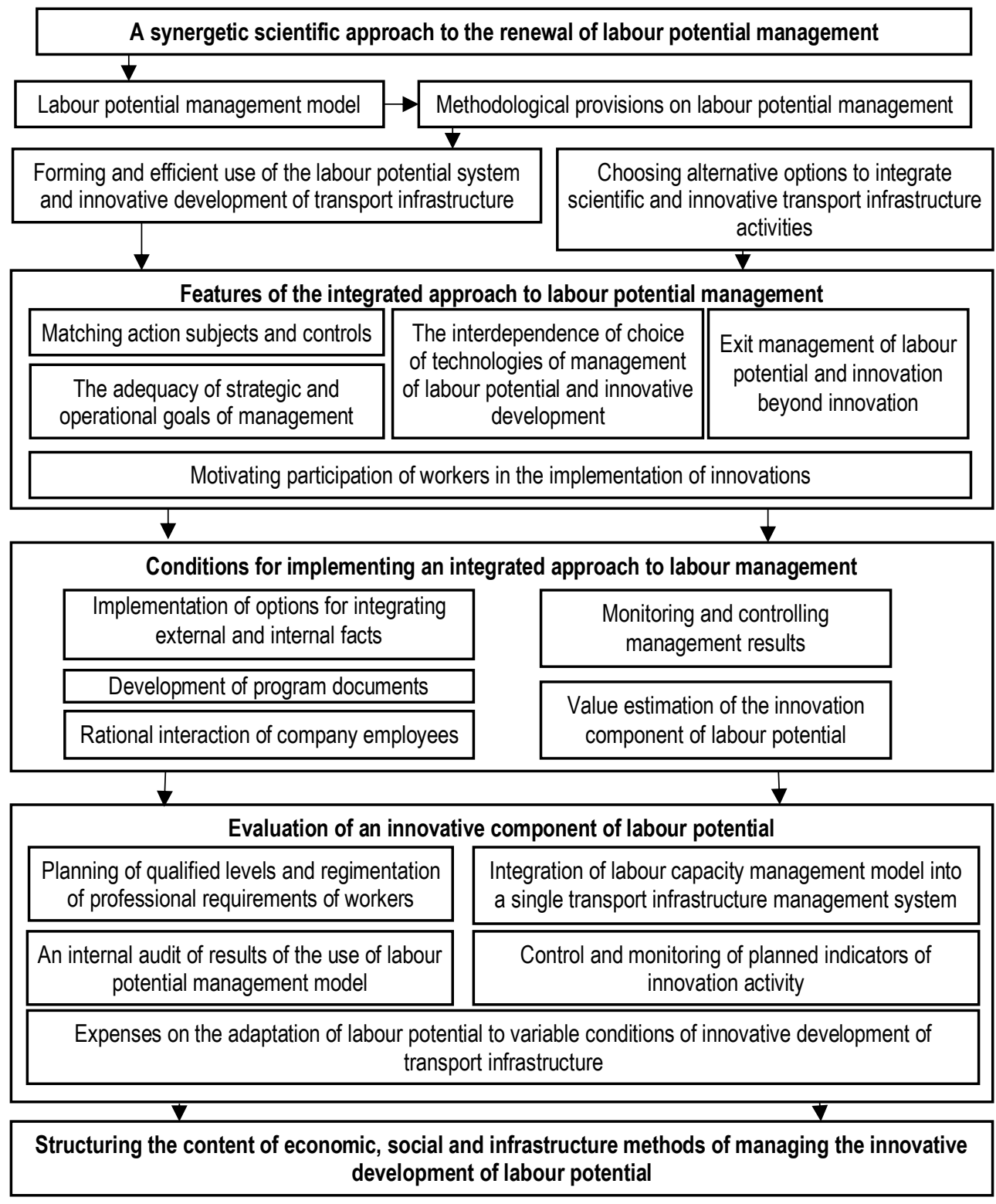

Figure 3. The concept of integrated management of labour potential in the conditions of innovative development of agro-industrial complex

Sources: developed by the authors.

Conclusions. In the conditions of strengthening the processes of European integration social vector of strategic development of the country requires development and implementation of new methods of management in all spheres of economic activity to increase the level of their competitiveness, especially. Implementation of the innovation model of the state economy will require substantial modernization 
transformations and complex use of not only modern technology, technology, but also scientific approaches to management, especially for ensuring sustainable development of priority segments of the national economy, which includes domestic agro-industrial complex.

Agro-industrial complex of Ukraine is the key budgetary element of the national economy. Considering the agrarian sector as a complex economic system, it is possible to assert that solving problems of evaluation and effective use of labour potential requires an integral approach, which becomes the foundation for the creation of universal methodical base. Development of evaluation of the efficiency of labour potential usage for solving regional problems on providing labour potential, based on the connection of general regularities of the process of preparation, acceptance and realization of management solutions. Application of the submitted methodological provisions will facilitate the further improvement of the methods of estimation of labour potential management, as well as the increase of readiness of employees to the perception of innovations.

Author Contributions: M. B. - the concept of integrated management of labor potential in the conditions of innovative development of agro-industrial complex is developed. O. P. - research works of domestic and foreign scientists, devoted to the outline of problems associated with the labor market are investigated; grouping and ranking of regions of Ukraine according to the convergence factor are conducted. I. P. - the methodical approaches to the estimation of economic efficiency of labor potential use by means of the determination of the convergence coefficient are proposed.

\section{References}

Buriennikova, N. V., Yarmolenko, V. O., Melnyk, O. V. (2017). Vyrobnychi resursy vydiv ekonomichnoi diialnosti Ukrainy: porivnialna kharakterystyka diievosti na bazi skladovykh rezultatyvnosti [Production resources of economic activity of Ukraine: Comparative characteristics of effectiveness on the basis of efficiency]. Nauchnyi vzgliad $v$ budushchee - Scientific look into the future, 6 (4), 4-13 [in Ukrainian].

Javier Cano-Urbina and Patrick L. Mason (2016). Acculturation and the labor market in Mexico. IZA Journal of Labor Policy, 5:21. Retrieved from https://izajolp.springeropen.com/articles/10.1186/s40173-016-0077-6.

Ritzen, Jo and Zimmermann, Klaus (2014). A vibrant European labor market with full employment. IZA Journal of Labor Policy, 3:10. Retrieved from https://izajoels.springeropen.com/articles/10.1186/2193-9012-3-10.

Konings, J. and Marcolin, L. (2014). Do wages reflect labor productivity? The case of Belgian regions. IZA Journal of Labor Policy, 3:11. Retrieved from https://izajoels.springeropen.com/articles/10.1186/2193-9012-3-11.

Kapitanets, Yu. O. (2011). Efektyvnist vykorystannia resursiv ahrarnoho vyrobnytstva [Effectiveness of agricultural production resources utilization]. Stalyi rozvytok ekonomiky - Sustainable development of the economy, 7, 59-63. Retrieved from http:www.gov.ua/portal/sos_gum/sre/2011_7/59.pdf.

Koval, O. M. (2010). Optymizatsiia efektyvnosti vykorystannia resursnoho potential silskohospodarskykh pidpryiemstv Ukrainy Retrieved from http:www.nbuv.-gov.ua/portal/cgem_biol/nvnau/2010_154_1/10kom.pdf.

Caliendo Marco \& Hogenacker Jens. (2012). The German labour market after the Great Recession: successful reforms and future challenges. IZA Journal of Labor Policy, 1:3. Retrieved from https://izajoels.springeropen.com/articles/10.1186/2193-9012-13.

Melnyk, O. V. (2017a). Suhasini aspekty stratehichnoho upravlinnia v ahrarnomu sektori ekonomiky Ukrainy [Modern aspects of strategic management in the agrarian sector of the economy of Ukraine]. Biznes Inform - Business Inform, 6, 111-116

Melnyk, O. V. (2017b). Vyrobnychi resursy ahrarnoho spriamuvannia: porivnialna kharakterystyka diievosti na mikro- ta makrorivniakh na osnovi skladovykh rezultatyvnosti [Production resources of Agrarian direction: comparative characteristics of efficiency on micro-and macrolevels on the basis of efficiency components]. Ekonomika. Finansy. Menedzhment: aktualni pytannia nauky i praktyky - Economy. Finance. Management: Actual questions of science and practice. Vinnytsia, 7, 65-71 [in Ukrainian].

Mochernyi, S. V. (2003). Ekonomichna teoriia [Economic theory]. Kyiv: Akademiia [in Ukrainian].

Bachmann, R., Bechara, P., Kramer, A., and Rzepka, S. (2015). Labour market dynamics and worker heterogeneity during the Great Recession - Evidence from Europe. IZA Journal of Labor Policy, 4:19. Retrieved from https://izajoels.springeropen.com/articles/10.1186/s40174-015-0043-0.

Viollaz, M. (2018). Enforcement of labor market regulations: heterogeneous compliance and adjustment across gender. IZA Journal of Labor Policy, 7:2. Retrieved from https://izajolp.springeropen.com/track/pdf/10.1186/s40173-018-0095-7. 
M. Butko, O. Popelo, I. Pishenin. Innovations in Human Resources Management in Eurointegration Conditions: Case for Ukrainian Agro-Industrial Complex

М. П. Бутко, д.е.н., професор, Чернігівський національний технологічний університет (Україна);

О. В. Попело, к.е.н., доцент, Чернігівський національний технологічний університет (Україна);

I. К. Пішенін, д.е.н., профресор, Київський інститут бізнесу і технологій (Україна).

Інновації в управлінні трудовими ресурсами в євроінтеграційних умовах: на прикладі підприємств агропромислового комплексу України

Темпи зростання економічного розвитку АПК і вплив дестабілізуючих фракторів на фуннціонування суб'єктів господарювання активізують низку проблем сталого розвитку аграрного сектору України. У сучасних трансформаційних умовах об'єктивна оцінка рівня економічної ефеективності використання ресурсного потенціалу підприємств агробізнесу в процесах планування, організації, контролю, аналізу і прогнозування перспектив його розвитку $\epsilon$ важливою складовою системи управління. На думку авторів, реалізація інноваційної моделі розвитку економіки держави потребує суттєвих модернізаційних перетворень $і$ комплексного використання не лише новітньої техніки, технологій, а й наукомістких підходів до менеджменту, передусім для забезпечення стійкого розвитку пріоритетних сегментів економіки України, до яких відноситься агропромисловий комплекс. Визначено, що агропромисловий комплекс України $\epsilon$ ключовим бюджетофрормуючим елементом економіки України. Розглядаючи аграрний сектор як складну економічну систему, автори стверджують, що вирішення проблем оцінки та ефективного використання трудового потенціалу потребує інтегрального підходу, який стає фрундаментом для створення універсальної методичної бази оцінки ефективності використання трудового потенціалу для вирішення регіональних проблем щодо забезпечення трудовим потенціалом, заснований на з'єднанні загальних закономірностей процесу підготовки, прийняття і реалізації управлінських рішень. У статті представлено комплексне оцінювання економічної ефективності використання трудового потенціалу за допомогою запропонованої авторами методики визначення коефріцієнта конвергенції. Проведено групування та ранжування регіонів України за коефріцієнтом конвергенції, за результатами якого виділено у групи регіонів: регіони з високим, вище середнього, середнім та низьким коефріцієнтом конвергенції. Розроблено концепцію інтегрованого управління трудовим потенціалом в умовах інноваційного розвитку агропромислового комплексу. Застосування представлених методологічних положень сприятиме подальшому удосконаленню методів оцінки ефективності управління трудовим потенціалом, а також підвищенню готовності працівників до сприйняття інновацій.

Ключові слова: трудовий потенціал, ринок праці, агропромисловий комплекс, оцінка ефективності; система управління, коефіцієнт конвергенції, інноваційний розвиток.

Manuscript received: 23.01.2019.

(C) The author(s) 2019. This article is published with open access at Sumy State University. 